\title{
So you've heard of the Gaskell medal: but who was Gaskell?
}

\author{
Digby Tantam, Senior Lecturer in Psychiatry, University of Manchester
}

The benefaction for the award of an annual medal and prize to a member of the Royal MedicoPsychological Association was made by Mrs Elizabeth Holland, in memory of her brother, Samuel. She was herself a remarkable woman, who married a banker, had ten children, translated poetry from the German, began a social club for unemployed men, founded a cottage hospital, and was well-known for her wit, conversation and unflappability. However, she came from a remarkable family. Her older brother, William, was a noted Unitarian minister, philanthropist, and writer. Her sister-inlaw, William's wife, was Mrs Elizabeth Gaskell, author of North and South, Wives and Daughters, and a celebrated, and for a season notorious, Life of Charlotte Brontë, as well as several other novels and short stories. Two of Elizabeth and William's children, Meta and Julia, were so well-loved in Manchester that flags flew at half-mast on their deaths.

Samuel was born in Warrington in 1807. Warrington at the beginning of the 19th century was a thriving industrial town, famous for its sail-canvas manufacture. Indeed half of the ships at Trafalgar boasted sails made in Warrington. It also had a strong tradition of dissenting Christianity. An academy had been founded in the town in the 18th century as an alternative to a university for those who would not swear to conform to the 39 articles, and Joseph Priestley had been an early teacher, of the British Constitution rather than chemistry surprisingly.

A Unitarian Chapel had been founded in Warrington in 1745, and the Gaskell family were among its staunchest members. The Gaskells were one of the principal non-conformist families in the North West, and had been involved in the foundation of the Academy and of the Public Library. Samuel's uncle, Holbrook, was a sponsor of Naismith, the machine-builder, and became a millionaire. His father, William Gaskell, was a successful sail-cloth manufacturer with a business in Buttermarket Street in the centre of Warrington. His mother, Margaret Jackson, the "handsomest and best lady married in Leyland Church for some time" as a contemporary newspaper said, had seven children of whom Samuel was the second. All of them were baptised in the Cairo Street Chapel and two, Margaret and John, died in infancy and were buried with their parents in the chapel yard.

Sam's father died at the age of 42, when Sam was 12. This must have been a difficult period for the family as Margaret had died at the age of six, three years before, and John died at the age of four, two years after. Margaret senior married again when Sam was 15 , to the Reverend Dimmock, a Unitarian minister.

Samuel wanted to become a doctor early in life, partly in response, perhaps, to the death of his sister, but the family were told by their general practitioner that Sam's eyes were too weakened by measles, and he was therefore apprenticed to a Liverpool publisher and book-seller. Both Sam and his older brother, William, had received private tuition at home from an Anglican minister, the Reverend Joseph Saul, and Sam took pleasure in reading many of the books he was required to sell, which included medical textbooks. Eventually Sam was remitted the last years of his apprenticeship and became apprenticed, at the age of 18, to Robert Thorpe, a surgeon at the Manchester Royal Infirmary. He subsequently studied in Glasgow where he qualified MRCS at the age of 25 and returned to Manchester, just at the time that cholera first reached Britain. Sam was appointed to Stockport Cholera Hospital. He continued to be interested in cholera subsequently, and even after he was appointed Commissioner in Lunacy was recommended by his sister-in-law Liza to Parthenope Nightingale as being ready to give her sister Florence "any information in his power" about the disease.

In 1834 Sam was appointed house apothecary to Manchester Royal Infirmary and its attached Lunatic Asylum which had been opened in 1766 with 22 beds. He became increasingly interested in the Asylum and in $\mathbf{1 8 4 0}$ applied for the post of resident medical superintendent of Lancaster Asylum. Although he had been criticised by the coroner for the death of a patient who drowned herself in the hospital pond before he left the Infirmary, he was fully exonerated and he received a glowing reference from his superior, Dr Bardsley, who wrote "I can most conscientiously state that it is impossible for any public Medical Officer to have excelled him in the exercise of these qualities"; these qualities being talent, diligence, application to duty, practical 
knowledge and moral conduct. After he left, the pond was drained without the consent of the hospital authorities on instructions from the police commissioners. His successor at the Infirmary was Joseph Holland who became the superintendent of the second asylum to be built in Lancashire, Prestwich Hospital.

Lancaster Asylum had been opened in 1816 following legislation in 1808 requiring counties to provide accommodation for mentally ill people. Its resident population rapidly grew from 60 in the first year to 406 in 1836 and, in the absence of a medical superintendent, patient management was increasingly custodial. Twenty-nine patients were in handcuffs, leg locks or strait-waistcoats when Sam took up his appointment, and 30 to $\mathbf{4 0}$ more were chained to boxed seats in heated rooms over a permanent sewer which did away with the need for them to move even to the toilet.

Sam set himself to remedy this situation as soon as he could. Restraints were minimised, games and slide-shows in the winter were introduced, and meat and tea appeared on the menu. Dances were organised at which one of the patients would play the violin. The situation at Lancaster improved so rapidly that Sam became well-known as a reformer. He was invited to assist in the plans for the new hospital (Cheadle Royal Infirmary) to replace his old workplace, the Manchester Lunatic Asylum, and his work was recommended by a visiting French psychiatrist as better than anything else he had seen in England. The Lunacy Commission had been granted more extensive powers of hospital visitation in 1845 , and in 1847 Lord Shaftesbury and other commissioners visited Lancaster Asylum. They were impressed by Sam's achievements, by his development of a library for the patients, by the institution of work for patients, by the encouragement of patients to help each other, and by the disappearance of the more unpleasant methods of treatment such as cupping and douching. Lord Shaftesbury resolved to appoint Sam to the Lunacy Commission as soon as there was a vacancy and this arose in 1849 .

Sam had read widely in psychiatry. Books preserved from the hospital library of that period include Cullen's Practice of Physic, Esquirol's Maladies Mentales, and books by Willis, Reid and Bell. There also an autobiographical account of an episode of psychiatric disorder by John Perceval, son of the assassinated Prime Minister Spencer Perceval, who had been confined in 1830 in conditions which the book protested strongly. It is likely that these works further encouraged Sam's philanthropy but also stimulated his scientific interest. His first report, in 1841, contains an interesting section on the causes of insanity. No cause could be found in $69 \%$ of the women and $60 \%$ of the men. Where a cause was alleged, the commonest cited were childbirth, death of friends, or disappointment in affection in women, and intoxication, epilepsy, and religion in men.

Sam had been a founder member of the Asylum Medical Officers Association and hosted the second meeting of its successor, the Royal MedicoPsychological Association, at Lancaster Asylum. He became interested in the increasing number of admissions of mentally handicapped children from the Lancashire and Yorkshire dales, and visited the Hopital Bicêtre in Paris, publishing an account of this visit in Chamber's Edinburgh Journal which advocated the separation of the care of the mentally ill and the mentally handicapped long before that became accepted practice.

His appointment as a Lunacy Commissioner came at a welcome time for Sam who was beginning to find the problem of long-stay patients a burden. He moved to London, and began a round of regular visits to asylums where he earned a reputation for "being a remarkably well-informed and painstaking official". His obituarist in the British Medical Journal goes on: "Proprietors and superintendents who did not look too greatly into details for themselves were greatly surprised, and not greatly pleased, to find the dignified Commissioner looking into beds and cupboards, and all manner of uninvestigated places". "It should never be forgotten that what is called the nonrestraint system is not alone the abolition of mechanical restraint, but that it connotes a revolution in the treatment of the insane in a great number of particulars, the neglect of which would render non-restraint, standing by itself, of comparatively little value. One of the more important adjuncts to non-restraint was the improved night-nursing, instituted by the late Mr Gaskell". Sam had introduced the practice of routinely toiletting incontinent patients at regular intervals, thus reducing the filth and stench often associated with the wards at night but also having the added advantage of ensuring that the nightattendants were awake and active. This resulted in a reduction of the suicides, violence and disturbance which had previously not been uncommon at night.

The attentions of the Lunacy Commissioners sometimes met with criticism not unknown to similar bodies today. After a visit by Sam and two of his colleagues, the committee of the Colney Hatch Asylum (now Friern Barnet Hospital) "observed with much regret that the more they have, from feelings of courtesy, listened to the representations of the Commissioners in Lunacy, the more that body has attempted to encroach on the functions of the Committee of Visitors, and to assume a tone of dictation...". Nor was this the only hazard of the job. One of Sam's colleagues on this visit was a lawyer, R. W. S. Lutwidge, who died after being attacked by a patient on an inspection of Fisherton House, Wiltshire, in 1873. 
In 1865 , when he was 58 , Sam was knocked down in a road traffic accident and, although he did not suffer any neurological damage, did complain of persistent symptoms which led him to resign his commission, and retire to Church House, Weybridge, Surrey. He lived a very quiet life for the next 20 years, and died at the age of 79, on 7 March 1886.

Sam never married, but he was close to Elizabeth Gaskell and her family. He kept a fatherly eye on Meta Gaskell when she was at school in London, and Meta attended his funeral. In later life, he also made many vists to Elizabeth Holland, and her large family in Wallasey.

Gaskell's only paper in a learned journal was the result of his evidence to a Select Committee of Parliament in $\mathbf{1 8 5 9}$ when he drew attention to the lack of provision for many non-violent mentally ill people who were deliberately overlooked by the local authorities required by the Poor Law to provide them with accommodation, in order to save costs. The paper included evidence of a similar sequestration of mentally ill relatives at home to avoid the expense of admission to hospital. He suggested a greater range of facilities catering for different levels of disturbance, and that patients could be voluntarily admitted.

Gaskell's readiness to adopt new ideas, his intelligence, his ability to get down to basics, and especially his practical concern for others would have stood him in good stead today. He was not inspired by the literary skills of his brother, sister, and sister-in-law to publish and we should be grateful to Elizabeth Holland for not only enriching the College, but for memorialising a psychiatrist whose distinction in public service would otherwise have been forgotten.

\section{Acknowledgements}

I am grateful to Miss Reddy, Librarian, Manchester Royal Infirmary; to the medical librarians of the John Rylands Library, University of Manchester; to Dr Berrios, Librarian of the Royal College of Psychiatrists; to the Archives Department, Warrington Borough Library; and to the Administrator, Lancaster Moor Hospital for assistance. I am also grateful to $\mathrm{Mr}$ Guest-Gornall for permission to use his father's unpublished manuscript on $\mathrm{Dr}$ Gaskell.

This paper is derived from a talk given at the Autumn meeting of the College in 1987, the centenary year of the founding of the Gaskell prize. A fuller version, with notes and references, is to be published in the Transactions of the Unitarian Historical Society, and I am grateful to the editor for permission to publish this extract.

\title{
Sketches from the history of psychiatry
}

\section{The fire at Colney Hatch Lunatic Asylum, 1903, remembered}

\author{
HenRy R. Rollin, Chairman, History of Psychiatry Group
}

On the night of $16 / 17$ November 1988 , fire destroyed a male ward at Friern Barnet Hospital in North London. Two patients died in the conflagration and one was injured.

This tragedy was in effect an action re-play on a very reduced scale of that which, in 1903, overtook the hospital, then known as Colney Hatch Lunatic Asylum. The disaster then was of such magnitude that newspapers and professional journals competed with each other in their graphic descriptions of the harrowing events, not only making it "the worst ever disaster in English asylum history' (Hunter
\& MacAlpine, 1974), but one which "occassioned the greatest loss of life of any in the metropolis since the great fire of 1666" (Journal of Mental Science, 1903).

In comparable vein, the opening paragraph of a long first leader in the Lancet of 31 January 1903, reads:

"In the early hours of the morning of January 27th there occurred a tragedy so appalling in its suddenness and heartrending by reason of its attendant circumstances that the barest and briefest record of the event brings horror to the mind. The temporary wards at Colney 